\title{
Impact of Bank Lending on Economics Growth in Pakistan: An Empirical Study of Lending to Private Sector
}

\author{
Safdar Husain Tahir ${ }^{1}$, Iqra Shehzadi ${ }^{1}$, Ishfaq Ali' ${ }^{2}$, Muhammad Rizwan Ullah ${ }^{1}$ \\ ${ }^{1}$ Department of Banking and Finance, Government College University, Faisalabad, Pakistan \\ ${ }^{2}$ Directorate of Sports, Department of Physical Education, Government College University, \\ Faisalabad, Pakistan \\ Email: safdartahir@gmail.com, iqra7145@yahoo.com, Ishfaqads@yahoo.com, \\ rizwan muhammad32@yahoo.com
}

Received 28 May 2015; accepted 24 August 2015; published 27 August 2015

Copyright (C) 2015 by authors and Scientific Research Publishing Inc.

This work is licensed under the Creative Commons Attribution International License (CC BY).

http://creativecommons.org/licenses/by/4.0/

(c) (†) Open Access

\section{Abstract}

Bank credit plays an important role in the economy of any nation. The current study examined the association among bank credit to private sector and economic growth in Pakistan. Economic growth was taken as dependent variable, while bank credit to private sector, interest rate, inflation, investment to GDP and government consumptions were taken as independent variables. Secondary data were collected from World Bank Indicator, ranging for the period 1973 to 2013. Descriptive research and correlation were used to check the normality of data. Unit root test was used to check the stationarity of variables. Co-integration VECUM and Granger Casuality test were statistically used to test the variable relationship and casuality effect of the variable. Regression analysis was used to analyze the impact of bank credit on economic growth. The findings of the study showed that bank credit had extensive relationship with economic progression; in short term the relationship was also significant. Regression analysis showed that there was adverse impact of bank credit on economic growth in Pakistan. However, problem associated with bank credit facility is the constraint and regulation imposed by SBP on the percentage of credit to be given to the Entrepreneurs. For solitary in the meantime bank lending has a casual influence on economic growth, there is a policy need to give devotion to liberalization the monetary sector.

\section{Keywords}

Bank Lending, Financial Development, Economic Growth, Co-Integration Component 


\section{Introduction}

The ever changing tendencies in globalization, forthcoming liberalization and the contemporary Asian business disaster, have fetched rehabilitated attention going on significance of the bank credit and its influence on commercial growth. Nowadays, a world without finance cannot be imagined. In simple words, finance is the soul for economic activities. Certain resources are needed to execute any economic undertaking, which are assembled in terms of money (i.e. in the arrangement of cash currency notes, coinage and other valuables, etc.). Finance is a precondition for attaining physical resources. That is needed to accomplish productive actions and performing business operations e.g. sales, unascertained liabilities pay compensations, reserve for contingencies and consequently on.

Credit played an important role in economic growth and development of the developing countries like Pakis$\tan$. The liquidity strains in the banking industry always limit the growth of the industrial sector of the country consequently taper the cumulative growth of the country. The distribution of credit to the different private sector has also significant impact upon the economic growth. In Pakistan, credit distribution was tilted towards capital intensive sector (industrial sector) and the flow of credit to priority sector like agriculture was found low.

Businesses habitually do not construct their resources organization fully by their owner equity capitals, in direction to fulfill their monetary needs of businesses particularly small partnerships which consume insufficient causes of floating resources (White and Cestone) [1], (Galor and Zeira) [2].

The basic function or role of banks and other financial institution in economy is to mobilize surpluses from income holders as their savings to others who need it on interest. Thus the banks convert the savings into loanable funds. These loanable funds are channel to investors who borrow to meet the financial need of their businesses.

\subsection{Connection between Bank Credit and Economic Growth}

Economic growth and bank credit adopted various studies. We can define economic growth as positive change in the level of establishment of goods and national income and services which are provided by country over a specific period of time. This is usually measured in terms of the level of production within the economy. Other parameters of growth which ranges from real per capital GDP, the velocity of corporeal capital accretion etc. (McKinnon) [3] (Allen and Ndikumama) [4], According to (Bencivenca \& Smith) [5], spending goods in the economy are shaped from labour and capital. An entrepreneur, who lends credit from the bank used for capital invested in the business, which he uses to utilize labour in respect to induce goods \& services for the Economic Growth.

Economy of Pakistan cannot develop and promote without appropriate monetary policy. The basic aim of economic policies is to enhance to promote the wellbeing of the general public. Monetary Policy accomplish this important objective through promote the price stability. The connection between financial development and production growth is bidirectional for all countries (Luintel and Khan) [6]. It means that the impact of credit is not always being positive on economic growth. It is not difficult to understand the real way in which the growth of credit influences economic growth. When credit grows, consumers can borrow and spend more, and enterprises can borrow and invest more. A rise of consumption and investments creates jobs and leads to a growth of both income and profit. Furthermore, the expansion of credit influences also the price of assets, thereby increasing their obtained value. The rise of asset prices offers the owner the chance to borrow more, due to the increase of wealth. This cycle of credit expansion leads to increased costs, investments, to the creation of new jobs, to prosperity, followed by a new loan, which produces the sensation of increased wealth, and which makes people feel happier as long as they are moving within the kingdoms of this ring. In order to increase economic growth with the help of credit, a more relaxed economic policy is required. There is completion of the privatization process as well as increased consumption of goods produced by economy. Finally, all economic expansion induced by credit comes to an end when one or more essential economic sectors become unable of paying off their debts.

Financial development can raise economic growth by increasing saving, improving assigned efficiency of loanable funds, and promoting capital accumulation. Moreover, a long sequence of contemporary empirical studies shows that a variety of financial indicators is strongly and positively associated with economic growth (Gurley and Shaw) [7], (Goldsmith) [8], (McKinnon) [3], (Shaw) [9], and (Beck et al.) [10]. Bank credit can be sub divided into two: credit to the private sector and credit to the public sector. This has been empirically proven 
that credit to the public sector is weak in generating growth within the economy because they are prone to waste and politically motivated programmers which may not deliver the best result to the populace.

\subsection{Theories}

One of the debates in growth theory is the extent to which financial development leads to economic growth. It is not implausible to posit a positive correlation between growth in the financial and real sectors. However, the causal relationship is not clear. Which is the cause and which is the effect? Is finance the leading engine for economic development or does it simply follow growth from elsewhere?

\subsubsection{Finance and Economic Development}

Financial intermediaries are important for growth. As economists since (Goldsmith) [8], (McKinnon) [3], and (Shaw) [9], have shown, financial development and economic growth are positively correlated across countries. (Schumpeter) [11], wrote that financial intermediaries promote growth by identifying and redirecting funds toward innovative projects.

"The essential function of credit consists in enabling the entrepreneur to withdraw the producers' goods which he needs from their previous employments, by exercising a demand for them, and thereby to force the economic system into new channels" (Schumpeter, [11], p. 106). This "supply leading" argument says that financial development is a determinant of growth. This is accomplished by the mobilization of savings and efficient allocation of resources; mitigation of the problem of asymmetric information, and monitoring of firms; and management of risk and reduction of transaction costs, among others. The opposing argument is that the causality runs the other way: economic growth creates a demand for financial intermediation. The creation of modern financial institutions and services is then a response to the demand from investors and savers in the economy.

\subsubsection{Supply Leading}

Modern theories explicitly show how financial intermediaries overcome market frictions and lower the cost to society of transferring information or wealth between households and firms. Many of the arguments inevitably lead to the idea that in one way or another financial intermediaries give individuals or firms the opportunity to achieve economies of scale, an option that may otherwise not have been available. Thus, intermediaries enhance economic efficiency and ultimately growth because they help allocate capital to its best possible use. In a world of perfect competition, perfect information, and no market frictions, there would be no role for financial intermediaries. Intermediaries Financial intermediaries are better at collecting information; providing expertise in evaluating, screening, and sorting prospects; and monitor firms' actions at a lower cost than individuals can. Financial intermediaries help capital move to its highest value, thus improving allocative efficiency.

As (Becsi and Wang) [10], argue, the intermediary can offer this service at a lower cost than savers can manage individually. Savers therefore have access to economies of scale not otherwise available to them. A final way that intermediaries help investors is by providing access to long-term projects through funds pooling and liquidity management. As a precaution in case of unexpected demands, savers usually prefer to have investments that are liquid.

\subsubsection{Demand Following}

In contrast to the supply leading thesis, the demand following thesis argues that financial development primarily follows economic growth and that the engines of growth must be sought elsewhere. Rising incomes from the agricultural or rural sector provide funds for which the financial intermediaries exist to service. Economic growth provides the demand which the finance sector fulfills. The primary function of intermediaries is to issue indirect debt, solicit funds from surplus units, and allocate it among debt units. (Gurley and Shaw) [7], contend that if income grows at a warranted pace, then the demand for financial assets also grows at a specifiable pace. In addition, there is a transactions demand for money to keep up with growing income. The accumulation of assets and rise in income stimulate demand by spending units for financial services in increasing variety. Financial development therefore follows economic development. Economic growth causes financial institutions to change and develop, and financial as well as credit markets to grow. Financial development is thus demand-driven. As the growing scale of economic activities requires more and more capital (liquid and fixed), institutional raising and pooling of funds for industry are substituted for individual fortunes to start up enterprises, and for retained profits for economic expansion. 


\section{Review of Literature}

Marco Pagano [12], checked the relationship between financial intermediation and economic growth. There are some financial factors that can affect growth are, funnelling saving to firms, improving the allocation of capital, affecting the saving rate and house hold borrowings. Financial intermediation can affect economic growth by acting on the saving rate, on the fraction of saving channelled to investment, or on the social marginal productivity of investment. Usually financial development has a positive effect on growth. They made some tests and tests of the models have shown that some of the forecast correlations are really present in cross-country data, but little is known about how the development of different markets affects economic growth.

Levine, Loayza and Bek [13], examine the casualty between financial intermediaries and economic growth. He used both traditional and recent techniques, instrumental variable procedures and cross sectional panel technique respectively. They found that financial intermediary's exogenous components for development are positively related to economic growth. Policy implications by the researcher after results were that the contract enforcement, accounting practices and legal reforms for accounting can accelerate financial development and boost up the economic growth.

Cottarelli, Giovanni Dell-Ariccia and Ivanna Vladkova-Hollar [14], examined the bank credit and its growth to GDP. They developed hypothesis that are these developments consistent through a process of conjunction and structural monetary extending by estimating an equilibrium level of bank credit to GDP ratio. They concluded that although there were no clear evidence that the recent increase in bank credit ratio is not consistence with financial development and economic growth. The policy implication for financial stability and macroeconomic development the policy makers will have to carefully evaluate the implications.

Ngai Wa [15], based on the model of augmented production function, explore a possible channel by which the banking industry can make its contribution to the productive capacity of the economy. He concluded that although the elasticity of output with respect to bank credit has fluctuated over time and exhibited a downward trend, our research does provide a possible channel by which the banking industry can make a quantified contribution to the growth of the economy. However, the contribution of domestic bank credit had been less significant in this growth process as large-scale tourism projects had been largely financed by foreign funds.

Usai and Vannini [16] investigate the role of specific categories of bank played in economic growth in Italy. Data was used for estimation during 1970 to 1993. By stemming the panel data regression model with fixed effect they concluded that the over-all magnitudes of financial sector have weal impact on local growth. Moreover co-operative and special credit banks have positive influence on growth that the public bank and national interest banks. These banks have negative impact on economic growth.

Vaithilingam, Guru and Shanmugem [17], analyzed the note of commercial bank lending on economic growth in Malaysia. By using VECUM model they found that real income is directly affected by an increase in commercial bank credit to private sector and vice versa. Researchers recommended that developing economies such as Malaysia that are highly dependent on banking sector should develop their capital market to position themselves against the reliance on private sector.

Nkurunziza [13], examine the effect credit and convergence on economic growth in Kenya in 1990s. The researcher found that firms that use credit grow faster than larger one.

Barros, Managi and Matousek [18], explore the productivity changes in Japan through bank credit. The data covered the period from 2000 to 2006. Through traditional accounting method of growth the researchers conclude that the analysis is ambiguous. The policy implications were that the management of Shinkin bank should have to improve.

Adams et al. [19], investigate empirically dynamic of relationship between bank lending, insurance and economic growth. They covered the study in Sweden and used time series data for the period 1830 to 1998 . The data was used through two test granger casuality and procedure of Toda and Yammato [20]. The second one used to non-stationary nature of time series data. The results show that credit and insurance is important perquisite to stimulate economic growth. Moreover for developing countries this could have important policy implications.

Aurangzeb [21], investigated the contributions of banking sector in economic growth of Pakistan. The data used in this study were collected from the period of 1981 to 2010 o 10 banks. Augmented Dickey Fuller (ADF) and Philip Perron unit root test, ordinary least square and granger causality test have been used. Unit root test confirms the stationary of all variables at first difference. Regression results designated that deposits, investments, advances, profitability and interest earnings have significant positive impact on economic growth of Pa- 
kistan. The Granger-Causality test confirms the bidirectional causal relationship of deposits, advances and profitability with economic growth. On the other side we found unidirectional causal relationship of investments and interest earnings with economic growth runs from investments and interest earnings to economic growth. It is recommended that the policy makers should make policies to enhance the banking sector in Pakistan because banking sector is significantly contributing in the economic growth of Pakistan.

Izhar and Ahmad [22], determined the relationship between financial indicators and human development in Pakistan. The objective of the study is to investigate the impact of financial indicators on human development in Pakistan by using annual data from 1975 to 2010. Data is analyzed by co-integration theory, Granger causality test and variance decomposition. Results indicate that causality runs from financial indicators to human capital except credit to private sector (CPS) but not vice versa. Financial indicators are closely associated with economic growth and human development in Pakistan.

\section{Research Methodology}

\section{Specifications of Econometric Model}

The specifications of econometric model based on econometric theory and on any information relating to the phenomenon being stated. In this study this model explained the independent and dependent and controlling variables.

Following model is used in this study.

$$
\mathrm{RGDP}=\alpha+\beta_{1} \mathrm{BP}+\beta_{2} \mathrm{IR}+\beta_{3} \mathrm{GC}+\beta_{4} \mathrm{IGDP}+\beta_{5} \mathrm{INF}+e
$$

where:

RGDP $=$ Real Gross Domestic Production which is dependent variable.

$\alpha=$ Intercept, $\beta$ shows coefficients.

$\mathrm{BP}$ is bank credit to private sector which is independent variable.

IR is Interest rate/rate of banks on lending to private sector, INF is Inflation/change in consumer price index, IGDP is investment to GDP and GC is government consumption to GDP, these are all controlling variables. $e$ denotes the error term.

\section{Empirical Results and Discussion}

\subsection{Descriptive Statistics}

Descriptive research of the study is presented in Table 1. Descriptive statistic Table 1 shows the normality of data. The mean of variables BP, GC, IGDP, INF, IR, and RGDP is 22.37525, 11.32800, 17.82650, 9.141200, 8.886457 , and 4.756500 respectively. The descriptive statistics of the study show the close relation among the variables it provides the most average value of the variables. Probability of variables should not exceed form 1 high probability of the data is RGDP is 1.007360 .

Table 1. Descriptive statistics.

\begin{tabular}{ccccccc}
\hline & BP & GC & IGDP & INF & IR & RGDP \\
\hline Mean & 22.37525 & 11.32800 & 17.82650 & 9.141200 & 8.886457 & 4.756500 \\
Median & 22.06000 & 10.82500 & 18.29500 & 8.110500 & 9.040000 & 4.645000 \\
Maximum & 28.13000 & 16.78000 & 20.82000 & 26.70000 & 17.78000 & 10.22000 \\
Minimum & 16.02000 & 7.780000 & 13.37000 & 2.504000 & 3.460000 & 1.0100 s00 \\
Std. Dev. & 2.975157 & 2.086842 & 1.697204 & 4.968825 & 3.297941 & 2.084777 \\
Skewness & 0.058361 & 0.724378 & -0.896586 & 1.566861 & 0.442376 & 0.410842 \\
Kurtosis & 2.557362 & 3.216490 & 3.293227 & 6.076448 & 3.015373 & 2.778073 \\
Jarque-Bera & 0.349254 & 3.576271 & 5.502418 & 32.14124 & 1.141910 & 1.207360 \\
Probability & 0.839770 & 0.167272 & 0.063851 & 0.000000 & 0.564986 & 0.546796 \\
Observations & 40 & 40 & 40 & 40 & 35 & 40 \\
\hline
\end{tabular}


Kurtosis results are best when it exceed from value three. The value of inflation, interest rate, government consumption, investment to GDP is greater than 3 it is best and kurtosis data is abnormal in BP and RGDP as it is less than 3.

When mean is less than median it means the sekwness is significant positive according to this table RGDP, INF, IR, BP and GC value is positive, and only IGDP has negative impact. Jarque-Bera also shows the normality of data all variables are positively tend to the normal range. Results are effective when the results of one variable are round about the results of other variable. Table show that the results are near to one another the high value is 4.968825 and the minimum standard deviation is 2.084777 . All variables are near to each other.

\subsection{Correlation Analysis}

INF and IR have negative correlation with BP and GC, IGDP and RGDP have positive correlation with BP. The highest correlation is in between IR and INF which means the problem of multicolinearity does not exist (Table 2).

\subsection{Unit Root Test}

The ADF and PP test were conducted by using Schwarz info criterion technique and the results for the unit root test of variables level as well as in first and second difference is presented in Table 3. In Table 3 ADF test values of variables are presented in level as well as with first and second difference as a pattern with intercept, trend and intercept and with none. The presences of unit root or the null hypothesis of non-stationary for any variable is not rejected when the absolute value of t-statistic is less than tabulated or critical value. The significance is checked from p-value. The critical values for the (H0) null hypothesis rejection are the same for both test $\mathrm{PP}$ and ADF.

For a model with linear trend, the critical value is at the $5 \%$ of level of significance. If p-value is greater than 5 percent we reject the null hypothesis and accepts the alternative that represented no unit root mean data are stationary. Based on the results of the unit root test, null hypothesis of non-stationary could not be rejected in

Table 2. Correlation matrix.

\begin{tabular}{ccccccc}
\hline & BP & GC & IGDP & INF & IR & RGDP \\
BP & 1.000000 & & & & & \\
GC & 0.137230 & 1.000000 & & & & \\
IGDP & 0.537513 & 0.414546 & 1.000000 & & & \\
INF & -0.084109 & 0.113755 & 0.053833 & 1.000000 & & \\
IR & -0.126976 & -0.029735 & -0.183156 & 0.601904 & 1.000000 & 1.000000 \\
RGDP & 0.039651 & 0.172305 & 0.279406 & -0.228057 & -0.398746 & \\
\hline
\end{tabular}

Table 3. Augmented Dickey-fuller unit root test.

\begin{tabular}{|c|c|c|c|c|c|c|}
\hline \multirow{2}{*}{ Variables } & \multicolumn{3}{|c|}{ Level } & \multicolumn{3}{|c|}{ First difference } \\
\hline & Int. & Trend \& Int. & None & Int. & Trend \& Int. & None \\
\hline RGDP & $-4.4013^{*}$ & $-0.6785^{*}$ & -5.56745 & $-5.3078^{*}$ & $-5.27619^{*}$ & $-5.38893^{*}$ \\
\hline $\mathrm{BP}$ & -3.29447 & -3.12974 & -0.35144 & $-4.1714^{*}$ & $-4.51762^{*}$ & $-4.23127^{*}$ \\
\hline INF & $-4.71932^{*}$ & $-4.54437^{*}$ & $-2.62926^{*}$ & $-6.8850^{*}$ & $-6.92118^{*}$ & $-6.92368^{*}$ \\
\hline GC & -1.46177 & -1.71805 & -0.09444 & $-5.74061^{*}$ & $-5.67153^{*}$ & $-5.82028^{*}$ \\
\hline IGDP & -2.67302 & -3.44204 & -0.10027 & $-6.35930^{*}$ & $-6.62218^{*}$ & $-6.45390^{*}$ \\
\hline IR & -3.38528 & -3.62823 & -1.07569 & $-8.48340^{*}$ & $-8.39647^{*}$ & $-8.62081^{*}$ \\
\hline
\end{tabular}

Note: The ADF test is generated by a model with intercept, trend and intercept and none for level test, first difference and second difference. The $\left({ }^{*}\right)$ indicate the rejection of null hypothesis at the $5 \%$ of level of significance. If p-value is $<0.05$ reject H0 and if p-value $>0.05$ we cannot reject the H0. H0: Variables has a Unit Root/ Non-stationery. H1: Variables has no Unit Root/ Stationery. 
levels for all series except for the ratio of inflation and RGDP using the ADF test. Variables exhibited stationary properties after first and second differencing. After first and second differencing the stationery of all variables indicate that the series concerned is integrated of order one and two, as the null hypothesis can be rejected only in the first difference and second difference at the $5 \%$ level of significance.

In case of contradiction in results of ADF and PP test the results of ADF prevail (Schwert) [23], \& (Arize) [24].

\subsection{Optimal Lag Length}

For undertaking cointegration and causality testing; it is necessary to examine the optimal lag structure. In this study VECM consisting of six variables is calculated. Model specification involve two major components; first selection of related variables to be incorporated in the model and the determination of the optimal lag length to be associated with the selected model (Table 4).

Optimal lag length included in the model is calculated by using the likelihood Ratio. Lag means the addition of previous value. Lag selection criteria told how much lags should be included.

Based on the results of likelihood ratio test presented in Table 5, it represent th optimal lag to be included in the system is one. This is subsequently used for the cointegration test and in VECM model.

\subsection{Cointegration Test}

There are three cointegration test Johansen Jusilius is the main one to find out the long term association among the variables in Johansen Jusilius there are many test but the most important are trace and maximum Eigen value statistic to show the association of all variables included in the model.

Results for the JJ cointegrastion test are presented in Table 6, which list the maximum Eigen value from a multivariate cointegration test of the system, under null hypothesis that the series are not cointegrated. Given that there are six variables in the model. There are at most five cointegrated vectors so that $r$ could be equal to null, 1, 2, 3, 4 or 5 . The value of test (Eigen value max) designate that null hypothesis of no cointegration is rejected when $r=$ none at $5 \%$ level of acceptance and significance. It provides the strong evidence of a stable presence of cointegrated vector among the set of variables.

\subsubsection{Trace Statistics}

Table 6 represent the outcome of Johansen's cointegration, the first results are trace statistics. The null hypothesis

Table 4. Lag-length selection.

\begin{tabular}{ccccccc}
\hline Lag & LogL & LR & FPE & AIC & SC & 27.46798 \\
0 & -456.3766 & NA & 26146.28 & 27.19862 & 29.29048 \\
1 & -351.5665 & $166.4632^{*}$ & $473.2048^{*}$ & $23.15097^{*}$ & $25.03647^{*}$ & $23.79398^{*}$ \\
\hline
\end{tabular}

*Indicates lag order selected by the criterion. LR: sequential modified LR test statistic (each test at 5\% level). FPE: Final prediction error. AIC: Akaike information criterion.SC: Schwarz information criterion. HQ: Hannan-Quinn information criterion.

Table 5. Unrestricted cointegration rank test (trace).

\begin{tabular}{ccccc}
\hline Hypothesized No. of CE(s) & No. of CE(s) & Trace statistic & 0.05 critical value & Prob. $^{* *}$ \\
\hline None $^{*}$ & 0.788894 & 117.3654 & 95.75366 & 0.0007 \\
At most 1 & 0.543920 & 66.03743 & 69.81889 & 0.0965 \\
At most 2 & 0.469332 & 40.12959 & 47.85613 & 0.2179 \\
At most 3 & 0.274670 & 19.22017 & 29.79707 & 0.2179 \\
At most 4 & 0.171392 & 8.622935 & 15.49471 & 0.4014 \\
At most 5 & 0.070672 & 2.418683 & 3.841466 & 0.1199 \\
\hline
\end{tabular}

Trace test indicates 1 cointegratingeqn(s) at the 0.05 level. ${ }^{*}$ Denotes rejection of the hypothesis at the 0.05 level. ${ }^{* *}$ MacKinnon-Haug-Michelis (1999) p-values. 
Table 6. Unrestricted cointegration rank test (trace).

\begin{tabular}{ccccc}
\hline Hypothesized No. of CE(s) & Eigen value & Max-Eigen statistic & 0.05 critical value & Prob. $^{* *}$ \\
\hline None $^{*}$ & 0.788894 & 51.32799 & 40.07757 & 0.0018 \\
At most 1 & 0.543920 & 25.90784 & 33.87687 & 0.3264 \\
At most 2 & 0.469332 & 20.90943 & 27.58434 & 21.13162 \\
At most 3 & 0.274670 & 10.59723 & 14.26460 & 0.2817 \\
At most 4 & 0.171392 & 6.204252 & 3.841466 & 0.5871 \\
At most 5 & 0.070672 & 2.418683 & 0.1199
\end{tabular}

Max-eigenvalue test indicates 1 cointegratingeqn(s) at the 0.05 level. ${ }^{*}$ denotes rejection of the hypothesis at the 0.05 level. ${ }^{* *}$ MacKinnon-HaugMichelis (1999) p-values.

that there is no cointegration is rejected at $5 \%$ of level of significance. At the same level the test statistics is more than critical value show that we can reject the null hypothesis. The rejection of null hypothesis indicates that there is one cointegration equation that is at most one. Here p value is $0.2179=21.79 \%$ which is more than $5 \%$ level of significance. There is one error term meaning that all the variables such as RGDP, IR, INF, IGDP, BP and GC have long term associationship.

\subsubsection{Maximum Eigen Value}

Table 7 represents the results of max Eigen value statistics that indicated no. of cointegration model to find out long run relationship. None indicates that there is no cointegration equation. The result shows that $\mathrm{p}$ value is less than $5 \%$ level of significance. And the max Eigen value is more than the critical value so we reject the null hypothesis and accept the alternative one that there is one cointegration equation and there is long term association among the variable in this study. Our second hypothesis is at most one is accepted because the p value here is $0.3264=32.64 \%$ which is more than $5 \%$, and here is max Eigen value is less than critical value here we accept the null hypothesis that at most one cointegration equation indicate that the variables have long term association.

\subsubsection{Granger Causality Test}

Test findings show that e RGDP rate caused on IGDP because it is probability asterisk value is less than 0.05 . When the value is less than 0.05 then it caused. RGDP caused on bank lending at 0.005 percent level of significance. Interest rate caused on inflation and IGDP at 0.02 and 0.006 percent of p value respectively. Interest rate also caused on bank lending with a rate of 0.0005. Inflation and bank credit have caused on each other. IGDP rate caused on bank credit.

\subsection{Vector Error Correction Model}

As the variables are cointegrated that is concluded from the cointegration test, the Error Correction Model is applied.

Table 8 represent the results of VECM are significant at 2.00 critical values indicating long-run equilibrium relationship among six variables. RGDP is hardly significant but IGDP is more significant. If there is an error in the equilibrium in the short run then $35 \%$ by RGDP, $8 \%$ IR, $6 \%$ by INF, $48 \%$ by IGDP, $3 \%$ by GC, $0 \%$ by BP in one period. Results show that there is inertia among variables. Moreover, in short run IGDP have significant effect on RGDP, Interest rate and government consumption and interest rate effect on RGDP, INF, and IGDP. However bank lending hardly significant impact inflation and more nearly significance to investment in short run.

\subsection{Regression Analysis}

The expression regression was presented by the English biometrician, (Sir Francis Galton) [25]. The regression analysis is very significant analysis to find out the independed regressors on depended regress. Coefficient indicates the relationship flanked by independent variables on depended variable. The Prob. show the level of significance that which value is significantly impact on depended variable. 
Table 7. Pairwise granger causality test.

\begin{tabular}{|c|c|c|c|}
\hline Null hypothesis & Obs & F-statistic & Prob. \\
\hline IR does not Granger Cause RGDP & 34 & 2.29338 & 0.1401 \\
\hline RGDP does not Granger Cause IR & & 3.06527 & 0.0899 \\
\hline INF does not Granger Cause RGDP & 39 & 0.08306 & 0.7748 \\
\hline RGDP does not Granger Cause INF & & 0.02784 & 0.8684 \\
\hline IGDP does not Granger Cause RGDP & 39 & 0.18172 & 0.6724 \\
\hline RGDP does not Granger Cause IGDP & & 12.9307 & $0.0010^{*}$ \\
\hline GC does not Granger Cause RGDP & 39 & 0.00098 & 0.9753 \\
\hline RGDP does not Granger Cause GC & & 0.33476 & 0.5665 \\
\hline BP does not Granger Cause RGDP & 39 & 0.20578 & 0.6528 \\
\hline RGDP does not Granger Cause BP & & 8.59668 & $0.0058^{*}$ \\
\hline INF does not Granger Cause IR & 34 & 1.43732 & 0.2397 \\
\hline IR does not Granger Cause INF & & 5.41432 & $0.0267^{*}$ \\
\hline IGDP does not Granger Cause IR & 34 & 0.87213 & 0.3576 \\
\hline IR does not Granger Cause IGDP & & 14.7708 & $0.0006^{*}$ \\
\hline GC does not Granger Cause IR & 34 & 0.07644 & 0.7840 \\
\hline IR does not Granger Cause GC & & 0.81239 & 0.3744 \\
\hline BP does not Granger Cause IR & 34 & 1.09675 & 0.3031 \\
\hline IR does not Granger Cause BP & & 14.9941 & $0.0005^{*}$ \\
\hline IGDP does not Granger Cause INF & 39 & 1.41959 & 0.2413 \\
\hline INF does not Granger Cause IGDP & & 0.01917 & 0.8906 \\
\hline GC does not Granger Cause INF & 39 & 0.10038 & 0.7532 \\
\hline INF does not Granger Cause GC & & 0.17151 & 0.6812 \\
\hline BP does not Granger Cause INF & 39 & 4.33017 & $0.0446^{*}$ \\
\hline INF does not Granger Cause BP & & 12.8014 & $0.0010^{*}$ \\
\hline GC does not Granger Cause IGDP & 39 & 0.88475 & 0.3532 \\
\hline IGDP does not Granger Cause GC & & 0.63434 & 0.4310 \\
\hline BP does not Granger Cause IGDP & 39 & $5.6 \mathrm{E}-05$ & 0.9941 \\
\hline IGDP does not Granger Cause BP & & 3.92237 & $0.0553^{*}$ \\
\hline BP does not Granger Cause GC & 39 & 2.13249 & 0.1529 \\
\hline GC does not Granger Cause BP & & 0.23452 & 0.6311 \\
\hline
\end{tabular}

In Table 9 the results of regression analysis are presented. Results indicate that investment has significant impact on RGDP, interest rate and inflation has negative but insignificant impact on RGDP, government consumption has positively insignificant impact on RGDP. The positive impact of variables shows that if there is increase in the value of government consumption and RGDP, RGDP will also increase and vice versa. The results of regression analysis of bank lending to private sector are also insignificant negative. 
Table 8. Vector error correction estimates.

\begin{tabular}{ccccccc}
\hline Error correction & D (RGDP) & D (IR) & D (INF) & D (IGDP) & D (GC) & D (BP) \\
\hline Coint Eq1 & $-1.75710^{*}$ & 0.25605 & 0.23116 & $7.12387^{* *}$ & 0.34912 & 0.01662 \\
& $(-0.354913)$ & $(0.083623)$ & $(0.067510)$ & $(0.422698)$ & $(0.034828)$ & $(0.002561)$ \\
D (RGDP (-1)) & -0.7093 & -1.43040 & -0.10654 & $-2.40632^{*}$ & -0.95905 & 1.31259 \\
& $(-0.141863)$ & $(-0.462516)$ & $(-0.030807)$ & $(-0.141364)$ & $(-0.094724)$ & $(0.200281)$ \\
& $-2.05611^{*}$ & -1.46330 & $2.84410^{*}$ & $2.68147^{*}$ & -0.66395 & -1.22435 \\
D (IR (-1)) & $(0.294316)$ & $(-0.338668)$ & $(0.588621)$ & $(0.112753)$ & $(-0.046938)$ & $(-0.133717)$ \\
& 1.20710 & -1.30391 & $-2.21098^{*}$ & 0.72345 & 1.06724 & -0.76166 \\
D (INF (-1)) & $(0.118692)$ & $(-0.207301)$ & $(-0.314332)$ & $(0.020897)$ & $(0.051829)$ & $(-0.057142)$ \\
& -0.58354 & 0.59897 & 0.84374 & -1.74323 & 1.39058 & 1.02717 \\
D (IGDP (-1)) & $(-0.218007)$ & $(0.361808)$ & $(0.455760)$ & $(-0.191313)$ & $(0.256579)$ & $(0.292789)$ \\
& 0.59796 & -0.33978 & -0.14232 & $-3.59204^{*}$ & 0.65016 & 0.33212 \\
D (GC (-1)) & $(0.241557)$ & $(-0.221930)$ & $(-0.083124)$ & $(-0.426264)$ & $(0.129716)$ & $(0.102368)$ \\
& 0.37693 & 0.54419 & 1.76023 & 1.89845 & 1.10711 & $2.84491^{*}$ \\
D (BP (-1)) & $(0.084888)$ & $(0.198157)$ & $(0.573163)$ & $(0.125595)$ & $(0.123141)$ & $(0.488839)$ \\
& -0.50495 & 0.01535 & -0.06416 & -1.35173 & 0.36634 & -0.15430 \\
\hline
\end{tabular}

Table 9. Regression analysis.

\begin{tabular}{|c|c|c|c|c|}
\hline Variable & Coefficient & Std. error & t-statistic & Prob. \\
\hline $\mathrm{BP}$ & -0.114331 & 0.141270 & -0.809308 & 0.4247 \\
\hline GC & 0.078587 & 0.172578 & 0.455375 & 0.6521 \\
\hline IGDP & 0.470989 & 0.222745 & 2.114473 & 0.0429 \\
\hline INF & -0.047854 & 0.117580 & -0.406992 & 0.6869 \\
\hline IR & -0.184576 & 0.126071 & -1.464070 & 0.1536 \\
\hline
\end{tabular}

Note: Dependent variable: RGDP.

\section{Conclusions}

This study investigates the integration among bank lending and economic growth in Pakistan over the period of 1974 to 2013. Both Angle and Granger, and Johansen and Jusilius cointegration techniques are used to estimate long run relationship while short run dynamics are modeled in VECM (vector error correction model).

Augmented Dickey-fuller and Phillips-Peron Unit Root Test confirm the stationary of all variables at first difference. The empirical results from both Engle and Granger and Johansen and Jusilius cointegration analysis demonstrate that the six variables have long term association for the time under consideration.

Both statistics in Johansen Jusilius indicate that there is one cointegretion equation which means that there is long run association among the variables. In short run there is inertia between two variables. RGDP is hardly significant but IGDP is more significant. If there is an error in the equilibrium in the short run then $35 \%$ by RGDP, $8 \%$ IR, $6 \%$ by INF, $48 \%$ by IGDP, $3 \%$ by GC, $0 \%$ by BP in one period. Results show that there is inertia among variables. Moreover, in short run, there is a significantly positive impact of IGDP on RGDP at 0.05 level of significance. However, no impact of IR, GC, INF and IR on RGDP is found in short run. Results indicate that investment has a significant impact on RGDP; interest rate and inflation have a negative impact on RGDP; gov- 
ernment consumption has a positive impact on RGDP. The positive impact of variables shows that if there is an increase in the value of government consumption and RGDP, RGDP will also increase and vice versa. The results of regression analysis of bank lending to private sector are also in negative.

\section{Policy Implications}

This is a significant outcome and could have imperative policy implications. The above findings have implication for the development in Pakistan. For one, since bank lending has a casual effect on economic growth, there is policy need to direct attention to liberalizing the financial sector.

\section{References}

[1] Cestone, G. and White, L. (2003) Anticompetitive Financial Contracting: The Design of Financial Claims. The Journal of Finance, 58, 2109-2142. http://dx.doi.org/10.1111/1540-6261.00599

[2] Galor, O. and Zeira, J. (1993) Income Distribution and Macroeconomics. The Review of Economic Studies, 60, 35-52. http://dx.doi.org/10.2307/2297811

[3] McKinnon, R.I. (1973) Money and Capital in Economic Development. Brookings Institution Press.

[4] Allen, D.S. and Ndikumana, L. (2000) Financial Intermediation and Economic Growth in Southern Africa. Journal of African Economies, 9, 132-160. http://dx.doi.org/10.1093/jae/9.2.132

[5] Bencivenga, V.R. and Smith, B.D. (1991) Financial Intermediation and Endogenous Growth. The Review of Economic Studies, 58, 195-209. http://dx.doi.org/10.2307/2297964

[6] Luintel, K.B. and Khan, M. (1999) A Quantitative Reassessment of the Finance-Growth Nexus: Evidence from a Multivariate VAR. Journal of Development Economics, 60, 381-405. http://dx.doi.org/10.1016/S0304-3878(99)00045-0

[7] Gurley, J.G. and Shaw, E.S. (1955) Financial Aspects of Economic Development. The American Economic Review, 515-538.

[8] Goldsmith, R.W. (1969) Financial Structure and Development. Yale U, New Haven.

[9] Shaw, E.S. (1973) Financial Deepening in Economic Development. Vol. 270, Oxford University Press, New York.

[10] Beck, T. and Levine, R. (2004) Stock Markets, Banks, and Growth: Panel Evidence. Journal of Banking \& Finance, 28, 423-442. http://dx.doi.org/10.1016/S0378-4266(02)00408-9

[11] Schumpeter, J. (1911) The Theory of Economic Development. Harvard Economic Studies, 46, 1911-1912.

[12] Pagano, M. (1993) Financial Markets and Growth: An Overview. European Economic Review, 37, 613-622. http://dx.doi.org/10.1016/0014-2921(93)90051-B

[13] Nkurunziza, J.D. (2010) The Effect of Credit on Growth and Convergence of Firm Size in Kenyan Manufacturing. The Journal of International Trade \& Economic Development, 19, 465-494. http://dx.doi.org/10.1080/09638190802617670

[14] Cottarelli, C., Dell’Ariccia, G. and Vladkova-Hollar, I. (2005) Early Birds, Late Risers, and Sleeping Beauties: Bank Credit Growth to the Private Sector in Central and Eastern Europe and in the Balkans. Journal of Banking \& Finance, 29, 83-104. http://dx.doi.org/10.1016/j.jbankfin.2004.06.017

[15] Wa, H. (2005) Bank Credit and Economic Growth in Macao. Monetary Authority of Macao, Macao.

[16] Usai, S. and Vannini, M. (2005) Banking Structure and Regional Economic Growth: Lessons from Italy. The Annals of Regional Science, 39, 691-714. http://dx.doi.org/10.1007/s00168-005-0022-x

[17] Vaithilingam, S., Guru, B.K. and Shanmugam, B. (2008) Bank Lending and Economic Growth in Malaysia. Journal of Asia-Pacific Business, 5, 51-69. http://dx.doi.org/10.1300/J098v05n01_05

[18] Barros, C.P., Managi, S. and Matousek, R. (2009) Productivity Growth and Biased Technological Change: Credit Banks in Japan. Journal of International Financial Markets, Institutions and Money, 19, 924-936. http://dx.doi.org/10.1016/j.intfin.2009.07.006

[19] Adams, M., Andersson, J., Andersson, L.F. and Lindmark, M. (2009) Commercial Banking, Insurance and Economic Growth in Sweden between 1830 and 1998. Accounting, Business \& Financial History, 19, 21-38. http://dx.doi.org/10.1080/09585200802667139

[20] Toda, H.Y. and Yamamoto, T. (1995) Statistical Inference in Vector Autoregressions with Possibly Integrated Processes. Journal of Econometrics, 66, 225-250. http://dx.doi.org/10.1016/0304-4076(94)01616-8

[21] Aurangzeb, K.A. (2012) Contributions of Banking Sector in Economic Growth: A Case of Pakistan. Review of Economics and Finance, 2, 45-54.

[22] Zaman, K., Izhar, Z., Khan, M.M. and Ahmad, M. (2012) The Relationship between Financial Indicators and Human 
Development in Pakistan. Economic Modeling, 29, 1515-1523. http://dx.doi.org/10.1016/j.econmod.2012.05.013

[23] Schwert, G.W. (1987) Effects of Model Specification on Tests for Unit Roots in Macroeconomic Data. Journal of Monetary Economics, 20, 73-103. http://dx.doi.org/10.1016/0304-3932(87)90059-6

[24] Arize, A.C. (1996) Real Exchange-Rate Volatility and Trade Flows: The Experience of Eight European Economies. International Review of Economics \& Finance, 5, 187-205. http://dx.doi.org/10.1016/S1059-0560(96)90043-X

[25] Darwin, F. (1968) Francis Galton, 1822-1911. The Eugenics Review, 60, 3-11. 